\title{
ШПИГУНСТВО ЯК ФОРМА ДЕРЖАВНОЇ ЗРАДИ
}

\author{
КОНЧУК Наталія Сергіївна - викладач кафедри УПДВ та ТЗ Національної \\ академії сухопутних військ імені гетьмана П.Сагайдачного \\ ЛЕМЕХА Роман Ігорович - к. ю. Н., доцент кафедри менеджменту та \\ соціально-гуманітарних дисциплін, Львівська філія ПВНЗ «Европейський \\ університет» \\ РУБЦОВ Володимир Васильович - к. ю. Н., доцент кафедри менеджменту \\ та соціально-гуманітарних дисциплін, Львівська філія ПВНЗ «Европейський \\ університет»
}

DOI 10.32782/NP.2021.1.15

Проаналізовано особливості об’єктивної сторони складу злочину «державна зрада». Він описаний як бормальний склад злочину, що свідчить про те, що обов'язковою ознакою об'єктивной сторони є лише суспільно небезпечне діяння. Констатовано, що шпигунство може бути вчинене $i$ шляхом дї, $i$ бездіяльності; $i$ за попереднъою пропозицією представника іноземної держави, $і$ з власноі інічіативи громадянина України.

Ключові слова: державна зрада, шпигунство, державна зрада у формі шпигунства, злочин, об'єктивна сторона.

Постановка проблеми

До недавнього часу в Україні зустрічалися лише поодинокі випадки вчинення державної зради, тому ст.111 КК України практично не застосовувалась. Разом із тим, навіть одиничний факт вчинення відповідного злочину становить серйозну небезпеку для нашої держави, оскільки в результаті вчинення відповідних дій може бути спричинена непоправна шкода суверенітетові, територіальній цілісності та недоторканності, обороноздатності, державній, економічній чи інформаційній безпеці України. Однак з 2014 року ситуація кардинально змінилася внаслідок активізації російської збройної агресії на сході України, насильницького протиправного відторгнення Кримської автономії та Севастополя від України, а також їх приєднання до Російської Федерації. Поширеними є випадки, коли спецслужби Російської Федерації намагаються здійснити масштабні вербування українських громадян, в основному, військових для вчинення ними державної зради. Нерідко наші співвітчизники самі свідомо йдуть на такий крок, зраджуючи інтереси України. У зв'язку з цим, гостро постало питання захисту кримінально-правовими засобами відносин, що забезпечують умови охорони основ національної безпеки України. Запорукою успішного виконання цього обов'язку $\epsilon$ не лише злагоджена діяльність підрозділів Служби безпеки України у боротьбі із злочинними зрадницькими проявами, але й ефективне реагування кримінального законодавства на будь-яку загрозу національній безпеці України.

\section{Стан дослідження}

Аналіз об’єктивної сторони складу злочину, передбаченого ст. 111 КК України у формі шпигунства, став об'єктом розгляду лише поодиноких авторів. Зокрема, це питання висвітлювалось у дослідженнях О.Ф.Бантишева, Ю.В.Бауліна, П.І. Гришаєва, Б.М. Діденка, О.О. Дудорова, С.В.Дякова, А.М.Демидової, М.I. Загороднікова,А.Д. Срмакова, І.А. Іванова, В.С.Картавцева, В.С. Клягіна, В.Г. Кундеуса, Ю.В. Ауценка, В.К.Матвійчука, М.I. Мельника, А.В.Мошняги, В.О. Навроцького, Е.О. Смирнова, В.Я. Тація, М.І Хавронюка, I.О. Харь, Р.А.Чорного, О.В. Шамари, В.М. ШАлапаченка та інших. Проте чимало питань, що стосуються кримінальної відповідальності за державну зраду, залишаються дискусійними 
або невирішеними, а зокрема: щодо доцільності криміналізації збирання відомостей, що становлять державну таємницю із метою їх передачі як закінченого злочину; щодо з'ясування моменту закінчення злочину, передбаченого ч.1 ст.111 КК України у формі шпигунства, що полягає в збиранні з метою передачі іноземній державі, іноземній організації або їх представникам відомостей, що становлять державну таємницю; щодо визначення конкретної форми державної зради тощо.

3 урахуванням зазначених напрацювань ми поставили за мету здійснити аналіз об'єктивної сторони складу злочину, передбаченого ст. 111 КК України у формі шпигунства.

\section{Виклад основних положень}

У КК України шпигунство виступає у двох аспектах: 1) як ознака об'єктивної сторони складу злочину, передбаченого ч. 1 ст. 111 КК України; 2) як окремий склад злочину (ст. 114 КК України). Розмежувальним критерієм цих посягань $є$ суб'єкт злочину. Вчинити злочин, передбачений ч. 1 ст. 114 КК України, може лише іноземець чи особа без громадянства, тоді як аналогічні дії з боку громадянина України отримають кримінально-правову оцінку як державна зрада. Ця форма державної зради полягає у вчиненні наступних дій:

1) передача іноземній державі, іноземній організації або їх представникам відомостей, що становлять державну таємницю;

2) збирання з метою передачі названим адресатам відомостей, що становлять державну таємницю. Зупинимось конкретно на кожній із них.

Так, під передачею ворожій стороні відомостей, що становлять державну таємницю розуміють усне повідомлення (безпосередньо, телефоном, радіо), вручення певних документів чи інших матеріальних носіїв інформації (безпосередньо, через посередників, з використанням тайників) або їх пересилання (з використанням поштового, електронного зв'язку тощо) безпосередньо адресату чи посереднику [1, с. 59; 2, с. 87]. При цьому сам спосіб передачі (в усній формі чи через інших осіб тощо) - кримі- нально-правового значення не має і на відповідальність не впливає [2, с. 87]. Окрім того, не має значення чи передаються представнику іноземної держави першоджерела (наприклад,оригінали документів) чи їх копії, або лише відомості про них (макети, опис технічних систем тощо) [3, с. 205-206].

3 вищезазначеного, на перший погляд, випливає, що передача громадянином України відомостей, які становлять державну таємницю може вчинятися лише шляхом дії. Однак виключити можливість передачі секретних відомостей шляхом бездіяльності не слід. На цю проблему у кримінально-правовій літературі звертали увагу О.Ф. Бантишев та О.В.Шамара. Зокрема, вказані автори також не виключають можливості вчинення аналізованої форми державної зради шляхом бездіяльності. Як аргумент наводять такий приклад. Громадянин України, котрий встановив злочинний зв'язок 3 іноземною розвідкою і працює на цілком секретному об'єкті, у службові обов'язки якого входить увімкнення протипідслуховувальної системи, у визначений час за завданням цієї розвідки не вмикає таку систему, у результаті чого секретні відомості стають відомими іноземній розвідці [4, с. 109]. Таким чином, передача в буквальному розумінні цього слова відомостей, які становлять державну таємницю, так і створення умов для ознайомлення іноземної держави, іноземної організації або їх представників з ними, підпадають під поняття передачі.

Більшість дослідників вважає, що передача секретних відомостей є закінченим злочином $з$ моменту їх вручення представнику іноземної держави, тобто з моменту,коли в адресата є фактична можливість розпорядитися [1, с. 60; 2, с. 87]. Однак, деякі 3 них переконані, що в такому випадку немає значення, наскільки сприйняті і чи взагалі були сприйняті адресатом зміст і суть цих відомостей $[4$, с. 110-111]. Видається, слід підтримати першу позицію, оскільки особа, яка передала відповідні відомості, вчинила всі необхідні дії для того, щоб представник іноземної держави міг ними розпоряджатися.

Потребує також з'ясування питання, чи виступатиме закінченим злочином передача громадянином України відомостей, що 


\section{Кримінальне право, кримінальний процес та криміналістика}

становлять державну таємницю, якщо така «допомога" взагалі може не використовуватись ворожим супротивником. Причиною цього можуть бути різні обставини. Перш за все, інформація, яку надано, може бути застарілою (вже відома представнику іноземної організації 3 інших джерел) або ж адресат може просто не повірити зраднику. Видається, що в такому випадку матиме місце закінчений замах на вчинення злочину, передбаченого ст. 111 КК України, оскільки винний виконав усі дії, які він вважав необхідними для надання допомоги ворожій стороні.

У подальшому необхідно розглянути зміст діяння «збирання» 3 метою передачі відомостей, що становлять державну таємницю, які прийнято трактувати як пошук та здобуття відомостей (шляхом візуального спостереження, опитування, виготовлення копій документів, зняття інформації 3 каналів зв'язку) із наступним їх зосередженням в одному або кількох місцях [4,с. 75; 2, с. 87]. Ю.В.Баулін з цього приводу зазначає, що «нерідко для отримання зазначених відомостей використовується найскладніша сучасна техніка (спеціально обладнані літаки, кораблі або автомашини, спеціально встановлені на суші чи на морі прилади для отримання розвідувальної інформації, вхід до інформаційних мереж тощо)» [3, с. 206].

Слід зазначити, що «оскільки й передача, й збирання в цьому разі вживаються для позначення недоконаності, то названі дії вважаються виконаними, а злочин - закінченим 3 моменту початку збирання чи передачі інформації або певних предметів - носіїв інформації» [2, с.83]. У зв’язку 3 цим у кримінально-правовій літературі не вирішеним залишається питання доцільності криміналізації збирання відомостей, що становлять державну таємницю із метою їх передачі як закінченого злочину.3 цього приводу можна виокремити два підходи. Зокрема, представники першого підходу вважають таку позицію законодавця виправданою. Аргументи, які наводяться на їі користь, полягають у тому, що діяння, які направлені на здобуття відомостей, що становлять державну таємницю, мають підвищений ступінь суспільної небезпеки. Від- повідно в подальшому передача таких відомостей ворожій стороні може завдати непоправної шкоди державі [5, с. 11]. Натомість, представники другого підходу переконані, що збирання з метою передачі певних відомостей ворожій стороні згідно із ч. 1 ст. 14 КК України може розглядатися як готування до їх передачі (умисне створення умов для вчинення злочину), тому слова «або збирання з метою передачі» у диспозиції ст. 114 КК України є зайвими [6, с. 120].

Вважаємо, що аргументи, які наводяться на користь першого підходу, є більш переконливими, оскільки державна зрада є одним із найтяжчих злочинів. Тому будь-які суспільно небезпечні дії, навіть і на ранній стадії, які направлені на шкоду національній безпеці держави, повинні присікатися відразу. Доречною у цій ситуації є позиція П.Л. Фріса, який зазначає, що аналіз судової практики свідчить про те, що ій абсолютно невідомі випадки притягнення до кримінальної відповідальності за дії, що характеризуються як готування до злочину у «чистому» вигляді (виняток становлять випадки, коли такі дії утворюють самостійні склади злочину). Вищевказаний автор вважає, що така ситуація зумовлена складністю процесу доказування по цій категорії справ i бажанням працівників правоохоронних органів здобути більш важливі докази вини особи. У зв'язку з тим останні фактично дають можливість злочинцю «заглибитися»у процес вчинення злочину, замість того, щоб припинити його на ранній стадії, допускаючи часто завдання злочином тяжких наслідків [7, с. 171].

В.М. Шлапаченко зауважує, що при вчиненні державної зради у формі шпигунства, збирання відомостей, що становлять державну таємницю, може здійснюватись як законними та незаконними способами [8, с.85]. Однак, видається, що якщо має місце злочинна мета, то спосіб є завжди незаконним. Слід зазначити, що у відповідності до ст. 34 Конституції України кожному громадянину надається право вільно збирати будь-яку інформацію, за умови, якщо не порушується закон. Однак Закон України «Про державну таємницю» від 21 січня 1994 р. № 3855-XII вказує на особливий вид інформації, доступ 
до якої має лише обмежене коло людей на підставі дозволу на ознайомлення 3 конкретною секретною інформацією відповідно до службових повноважень особи (п. 6 ст. 1). Тобто держава на законодавчому рівні унеможливлює правомірне отримання відомостей, що становлять державну таємницю, не уповноваженими особами. Звідси випливає, що звичайному громадянину України законним способом (наприклад, 3 дозволу сфотографувати чи переписати відомості, що становлять державну таємницю) неможливо здобути відповідну інформацію. При цьому важливо встановити, що для відповідальності за ст. 111 КК України необхідно, щоб відомості, які становлять державну таємницю, були передані чи збиралися для передачі саме іноземним державам, іноземним організаціям чи їх представникам.

Однак, якщо особа, яка не мала на меті збирати секретні відомості, і не порушуючи закону (знайшла, випадково почула «секретоносія»), отримала інформацію, яка становить державну таємницю, а потім вирішила, що може таким чином підзаробити, якщо передасть такі відомості ворожій стороні, то за таких умов вона буде притягнута до кримінальної відповідальності не за збирання відомостей з метою передачі іноземній державі, а за передачу таких відомостей. Звідси випливає, що кримінально-правовій забороні можуть підлягати лише злочинні способи збирання.

Конкретних таких способів можна навести безліч (шляхом шантажу, шахрайства, вимагання, підкупу чи шляхом застосування насильства тощо). I вони, безумовно, впливають на кримінально-правову кваліфікацію. Для прикладу, якщо збирання відомостей, що становлять державну таємницю, 3 метою передачі їх ворожій стороні поєднане iз незаконним використанням спеціальних технічних засобів негласного отримання інформації, то такі дії отримають кримінально-правову оцінку за сукупністю (ч. 1 ст. 111 та ст.359 КК України).

Таким чином, лише передача та збирання відомостей, що становлять державну таємницю, з метою їх передачі, є діями, що фактично становлять об'єктивну сторону шпигунства як форми державної зради.
У такому випадку потребує з'ясування, яку кримінально-правову оцінку отримають дії особи, яка зберігає вищезгадані відомості за вказівкою представника іноземної держави чи організації? Безумовно, що коли особа збирає секретні відомості, то вона їх i зберігає до тих пір, поки не збере всю необхідну інформацію. Однак у цьому випадку мова йде про те, коли громадянин України не вчиняє жодних дій щодо накопичення відповідних відомостей, а лише їх зберігає (наприклад, представник іноземної держави (ворожої сторони), доручає громадянину України зберігати зібрані чи викрадені ним чи третьою особою відомості, що становлять державну таємницю. Через деякий час громадянин України повертає представнику ворожої сторони відповідні відомості. При цьому громадянин ці документи не збирав, а лише їх передав, однак ці відомості вже були відомі ворожому супротивнику. Звідси випливає, чи відноситься зберігання до поняття «збирання» i, відповідно, чи наступатиме відповідальність за шпигунство як форму державної зради).

Великий тлумачний словник української мови поняття «зберігати» трактує як тримати що-небудь у певних умовах, оберігаючи від псування, руйнування; дбаючи, тримати що-небудь у доброму стані; намагатися залишити незмінним; дбайливо ставитися до чого-небудь; не розтрачувати чогось [9, с. 1422]. Отже, зберігання - це діяльність зберігача, спрямована на забезпечення наявності у нього предмета зберігання, його недоторканності та зовнішньої незмінності [10, с. 246].

Видається, що в цьому випадку є всі ознаки державної зради. Такі дії можна розглядати як третю форму державної зради надання громадянином України допомоги іноземній державі, іноземній організації або їх представникам у проведенні підривної діяльності проти України, оскільки винний посприяв представнику іноземної держави чи організації шляхом укриття відомостей, що становлять державну таємницю, знаючи, що подальше використання ворожою стороною таких відомостей є загрозою для національної безпеки України. Таким чином, саме зберігання відомостей, що становлять 


\section{Кримінальне право, кримінальний процес та криміналістика}

державну таємницю, не слід відносити до форм шпигунства при державній зраді.

He менш дискусійним залишається з'ясування моменту закінчення злочину, передбаченого ч. 1 ст. 111 КК України, у формі шпигунства, що полягає в збиранні 3 метою передачі іноземній державі, іноземній організації або їх представникам відомостей, що становлять державну таємницю. 3 цього приводу можна виокремити дві позиції. Зокрема, представники першої позиції розглядають шпигунство у формі збирання злочином із формальним складом, а відтак, пов’язують момент закінчення відповідного злочину з моментом заволодіння певним обсягом секретних відомостей [11, с. 50],відповідно, представники другої позиції відносять шпигунство у формі збирання секретних відомостей до усіченого складу злочину (має місце тоді, коли у диспозиції статті Особливої частини КК України як ознака об'єктивної сторони вказується на незакінчене діяння) і визначають момент закінчення цього злочину з моменту початку збирання відомостей як процесу [1, с. 60; 2, с. 87].

3 одного боку, видається, що лише початок збирання секретних відомостей не дає «повної картини» щодо намірів особи (оскільки кримінально-караним є збирання відповідних відомостей саме 3 метою їх передачі), тобто чи збирає вона інформацію задля власної цікавості, чи рішуче вирішила ії передати представнику іноземної держави. Тобто в такому випадку правозастосовним органам у випадку затримання особи, яка збирає відомості, що становлять державну таємницю, буде складно довести факт, що відповідна особа діє проти інтересів держави. Однак, з іншого боку, питання доведення мети - це «справа» тих, хто застосовує закон. Тому, очевидно, не можна тлумачити закон, виходячи з труднощів, які можуть виникнути перед правоохоронними органами. Окрім того, підхід з приводу визнання злочину закінченим з моменту заволодіння певним обсягом секретних відомостей розмиває межу між об'єктивними та суб'єктивними ознаками та не базується на законі, оскільки КК України прямо вказує на саме збирання з метою передачі. За таких умов слід підтримати думку тих авторів, які визначають момент закінчення цього злочину з моменту початку збирання відомостей як процесу.

Потрібно також з'ясувати, чи властиве шпигунству попереднє отримання громадянином України певного злочинного завдання, пов'язаного із передачею чи збиранням 3 метою передачі секретних відомостей іноземній державі, іноземній організації чи їх представникам? Видається, що шпигунство також може вчинятись як за попередньою пропозицією представника іноземної держави,так і з власної ініціативи громадянина України. Прикладом останнього може бути звернення військовослужбовця Збройних Сил України до представника іноземної держави та повідомлення останньому, що має секретні дані про польоти винищувачів Повітряних сил Збройних сил України, маршрути рухів тощо, які може їх надати за умови грошової винагороди. У випадку ж отримання злочинного завдання і надання згоди на його виконання, так як і в першій формі державної зради, матиме місце готування до вчинення вказаного злочину у формі шпигунства, що може виступати передумовою звільнення від кримінальної відповідальності за умов, які передбачені ч. 2 ст. 111 КК України.

\section{Висновки}

Таким чином, шпигунство полягає у вчиненні наступних дій: передача іноземній державі, іноземній організації або їх представникам відомостей, що становлять державну таємницю; збирання з метою передачі названим адресатам відомостей, що становлять державну таємницю. У свою чергу, передача в буквальному розумінні цього слова відомостей, які становлять державну таємницю, так і створення умов для ознайомлення іноземної держави, іноземної організації або їх представників з ними, підпадають під поняття передачі. Збирання відомостей, які становлять державну таємницю, 3 метою їх передачі, здійснюється завжди незаконними способами, оскільки якщо має місце злочинна мета, то спосіб є завжди незаконним. 


\section{Література}

1. Кримінальне право (Особлива частина): підручник / За ред. О.О. Дудорова,Є.О. Письменного. Т. 1 - Ауганськ: Видавництво «Елтон-2», 2012 р. 780 с.

2. Навроцький В.О. Кримінальне право України. Особлива частина: Курс лекцій. К.: Т-во «Знання», КОО, 2000. 771 с.

3. Баулін Ю.В. Звільнення від кримінальної відповідальності: [монографія] / К.: Атіка, 2004. С.211-212.

4. Бантишев О.Ф., Шамара О.В. Кримінальна відповідальність за злочини проти основ національної безпеки України (проблеми кваліфікації) / Монографія. - К.: Видво НА СБ України, 2004. 168 с.

5. Альтшулер И.К. Развитие советского законодательства по борьбе с государственными преступлениями (ст. 58 УК РСФСР) в период до Великой Отечественной войны: автореф. дисс. на соискание ученой степени канд. юрид. наук / М., 1955. $14 \mathrm{c}$.

6. Хавронюк М.І. Довідник з Особливої частини Кримінального кодексу України. К. : Істина, 2004. 504 c.

7. Фріс П.А. Кримінальне право України: Загальна частина: підруч. для студ. вищ. навч. закладів / К. : Атіка, 2004. 488 с.

8. Шлапаченко В.М. Шляхи удосконалення кримінальної відповідальності за шпигунство у формі збирання (ст.114 КК України). Інформаційна безпека людини, суспільства, держави. № 1 (14). 2014. C.84-94.

9. Великий тлумачний словник української мови (з дод. і допов.). / Уклад. і голов. ред. В. Т. Бусел. - К.: Ірпінь: ВТФ «Перун», 2005. 1728c.

10. Донець А.Г. Поняття «зберігання», «схоронність», «охорона» та їх співвідношення. Державне будівництво та місиеве самоврядування. Випуск 24. 2012 р. С.242 - 252.

11. Картавцев В.С. Кримінальна відповідальність за злочини проти основ національної безпеки України (наукові засади кваліфікації): [навч. посіб] / К. : Вид-во НА СБ України, 2004. 57 с.
The peculiarities of the objective side of the crime "State treason» are analyzed. It is described as a formal crime, indicating that the obligatory indication of the objective side is only a socially dangerous act. It was stated that the transition to the enemy's side and espionage can be committed both by action and inaction; on the basis of a previous proposal by a representative of a foreign state, and on his own initiative, a citizen of Ukraine.

The state of theoretical study of the issue of criminal responsibility for state treason was conducted. A brief review of criminal literature has given an opportunity to conclude that the issue of criminal responsibility for state treason is one of those who have not been properly resolved.

It is stated that the crime provided for in art. 111 of the Criminal Code of Ukraine, taking into account its direct object, should be attributed to so-called «multi-objective» crimes, which at the same time cause damage to several groups of social relations, which are alternative and completely independent objects of the corresponding crime. The state of treason is the subject of the crime of state treason, which is clearly defined in the areas in which it can exist (in the field of defense, economy, science and technology, external relations, in the field of state security and law and order). Accordingly, if a citizen of Ukraine, who has provided information to a foreign state, a foreign organization or their representatives that does not correspond to any of the signs of state secrets, is not subject to criminal liability for state treason committed in a way of espionage.

Key words: high treason, espionage, the crime of high treason in the form of espionage, crime, the objective side. 